\title{
Physiochemical Alterations and Air Pollution Tolerance Index in Ficus religiosa L. Planted Along Polluted Roadsides of Lahore City
}

\author{
IRUM BASHIR ${ }^{1}$, MUHAMMAD UMER FAROOQ AWAN ${ }^{1 *}$, SOHAIB MUHAMMAD ${ }^{1}$, \\ ANDLEEB ANWAR SARDAR ${ }^{1}$, MUHAMMAD LUQMAN ${ }^{2}$, FARIHA AROOJ ${ }^{2}$ \\ ${ }^{1}$ Department of Botany, Government College University Lahore \\ ${ }^{2}$ Department of Environmental Sciences, University of Veterinary and Animal sciences (UVAS), Lahore
}

\begin{abstract}
Air pollution is among the nastiest form of pollutions causing vexation over the globe. The recent situation of eco-toxicity showed that whole planet is facing this misery explicitly or implicitly. The essence of this enigma is rapid urbanization and industrialization. Global developmental activities, deforestation, uncontrolled industrial emission and increase in vehicular load made this environment unfit for healthy life. This research work explored the effect of air pollution on physiochemical attributes of Ficus religiosa L. planted along the polluted roadsides of Lahore city. Leaf area, ascorbic acid contents (AAC), total chlorophyll content (TCh), $p H$ of leaf extract, relative water contents $(R W C)$, and dust accumulation on leaves surface were measured using standard methods. Air Pollution Tolerance Index was computed, and the results were compared with the control plants from Changa Manga forest, $70 \mathrm{Km}$ away from Lahore city in cleaner locality. Several Physiochemical alterations in F. religiosa growing in polluted arias were observed, including average leaf area $\left(1367 \pm 14.25 \mathrm{~mm}^{2}\right), A A C(0.68 \pm$

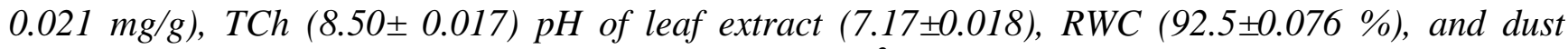
accumulation on leaves surface $\left(0.0716 \pm 0.00063 \mathrm{mg} / \mathrm{cm}^{2}\right)$ compare to control. The recorded average APTI value (10.32 \pm 0.023$)$ was higher in the plants grown along the polluted roads compared to controls (9.39 \pm 0.012$)$. It is concluded from the results that air pollution tolerance level of Ficus religiosa L. was higher along the polluted roads of Lahore. It depicts that they are considerably affected the prevailing air pollution.
\end{abstract}

Keywords: air pollution, urbanization, APTI

\section{Introduction}

Pakistan is the 5th susceptible country affected by global climate change, while its contribution in greenhouse Gas emission is less than 1\%, which is lowest rate among the globe. Air pollution is not only destroying human health but has also deep effect on Plants. Air of urban areas including vehicular exhaust contains high levels of pollutants [1]. Air pollution is linked to harmful substances in the air such as liquid droplets, solid particles or gases. Traffic related air pollutants are classified into primary and secondary pollutants. Primary pollutant includes oxides of carbon, sulphar and nitrogen whereas, secondary pollutant covers $\mathrm{O}_{3}$ and the other minor pollutants [2]. Lahore is the second biggest city of Pakistan. According to recently conducted census it houses 11.1 million individuals [3]. It is considered as cultural, economic, political educational and entertainment hub. It is located between $31^{\circ} 32^{\prime} 59^{\prime \prime} \mathrm{N}$ longitude and $74^{\circ} 20^{\prime} 37^{\prime \prime}$ E latitude covering an area of $1,772 \mathrm{~km}^{2}$ [4].

In the Lahore city transport sector is remarkably increased, with increase in metro projects and housing construction projects [5]. In the last ten years, the road transport has increased in a greater rate in all the cities of Pakistan, especially in Lahore [6]. Air pollutants from vehicular exhaust remain in atmosphere, but later these pollutants are gathered on the surfaces of land or reach to the earth surface with rain water.

*email: dr.umerfarooqawan@gcu.edu.pk 
Air pollutants, especially in urbanized cities, contribute in acid rain. Because of suspension of particulate matter in air these pollutants are not only responsible for bad air quality but they are harmful to plants and human health [7]. For Example $\mathrm{NO}_{2}$ produce low level ozone when they react with hydrocarbons, low level ozone $\left(\mathrm{O}_{3}\right)$ reduces lung function and trigger asthma [8]. Along with this $\mathrm{CO}$ reduces the ability of blood to carry oxygen which causes respiratory problems and headache Continuous interaction to these air pollutants can results allergies, skin diseases, cardiovascular diseases and premature mortality in human beings [9]. Vehicular air pollutants in plants results in foliar damages in sensitive species and less in tolerant species, stunted growth, visible leaf injuries, early fall of buds, reduced photosynthesis, and impaired physiology [10].

Urban forest helps in reduction of air and noise pollution, controlling soil erosion and enhancing the natural beauty of an area. Trees are planted around railways, roadside, rivers, banks, gardens, parks and playgrounds [11]. In urban areas the quality of air can be improved by greenbelt. Environmental pollution can be analyzed by using biosensors. Bacteria (Salmonella typhimurium, E.coli) animals (insect, mammals, fish, and worms) and plants (Tradescantia sp., Vicia faba) were successfully used as biosensors in the past [12].

Native trees of Lahore city are Ficus benghalensis L., Ficus religiosa L., Ficus retusa L., Livistonia chinensis L., Alstonia scholaris L., Erythrina suberosa L., Bombax malabaricum L., Mimusops elengi L., Callistemon citrinus L., Dalbergia sissoo L., Delonix regia L., Mangifera indica L., Syzygium cumini L., Kigelia pinnata L., Ziziphus L., Pongamia pinnata L. [13]. Ficus religiosa L. is the oldest planted tree in Lahore city. Large tree of Ficus religiosa L. is $30 \mathrm{~m}$ long. The color of bark is white or brown. Their leaves are shiny, thin, cordate shape and have 5-7 veins. Leaf blade is $10-20 \mathrm{~cm}$ long and 7-15 cm wide. Leaves of Ficus religiosa L. increase in size in 9 days from about 425 to $4025 \mathrm{~mm}^{2}$ after its emergence from bract. Its canopy is irregular and coarse textured [14]. Ficus religiosa L. is planted along polluted areas because of its large canopy and large number of leaves. One tree of Ficus religiosa L. release considerable amount of oxygen that fulfill the oxygen requirement of 6 persons per day [15]. Oxygen production depends upon the diameter, health and growth rate of tree. During a year net oxygen produced by a tree is directly related to long term storage of atmospheric carbon. Carbon sequestration increase with increase in tree biomass. Ficus religiosa L release more oxygen because it yields more biomass per unit area [16,17].

Physiochemical characters are under the influence of environmental pollution. Decreased chlorophyll content and increased ascorbic acid content was observed as a result of air pollution in plants which ultimately leads to death of plants. The amount of photosynthetic pigments like chlorophyll and carotenoid is reduced in leaves as a result of absorption of air pollutants and caused reduction in plant yield $[18,19]$. Ascorbic acid play role in detoxification, cell expansion, cell division of plant cells [20]. The protein synthesis under stress condition (excessive $\mathrm{CO}, \mathrm{SO}_{2}, \mathrm{NO}_{2}$ ) is affected. It has been observed that many genes $\left(\mathrm{HD}_{2}\right)$ are very sensitive to environmental pollution. The main objective of this research work is to study the relationship between roadsides pollution and physiological parameters, biochemical parameters and their regulation under air pollution stress.

\section{Materials and methods}

Physiochemical characteristics of Ficus religiosa L. under influence of air pollution along different road sides of Lahore city was find out through different parameters like leaf surface area, dust accumulation on leaves, while atomic absorption spectrum analysis of deposited dust on the leaves, was also determined. Along with these parameters, estimation of Ascorbic Acid Content (mg/g), Total Chlorophyll content (TCh), Leaf Extract $p \mathrm{H}$, \%Relative Water Content (RWC\%) was carried out to determine the Air Pollution Tolerance Index (APTI) of the selected plant species.

\subsection{Selection of study sites}

Lahore (The city of gardens) facing huge pressure of air pollution not only affecting humans but also have drastic effect on plants. Ficus religiosa L. is one of the native trees of Lahore city planted on the 
road sides and into the park. The present research work is planned to study the effect of air pollution on Physiochemical alterations in Ficus religiosa L planted along the polluted roadsides of Lahore city. Three roads for experimental sampling in Lahore via Jail road, Mall road and Canal road were selected. These sites are characterized with high density of vehicles. The control trees were selected from Changa Manga District Kasur which is $80 \mathrm{~km}$ away from Lahore city with very low traffic flow and less air pollution as well.

\subsection{Calculation of leaf area}

To calculate the surface area of leaves, leaf samples were drawn on graph paper. Petiole was only drawn and was removed from other drawing. To calculate the leaf area squares located within the leaf area drawing were counted and multiplied those with $1 \mathrm{~cm}$. Partial squares within the leaf area were counted, and divided by 2 .

\subsection{Calculation of dust accumulation}

About 10-15 matured leaves of Ficus religiosa L. from selected sites were collected in polythene bags. Leaves were collected at the height of 3-4 meters from all the sites. First of all weigh of intact leaf was measured and then dust from surface of leaves were gently collected with the help of camel hair brush and weighed leaves as described by [21]. Dust accumulation on leaves surface of Ficus religiosa L. from selected sites of Lahore city was calculated by following formula.

where:

$$
\mathrm{W}=\left(\mathrm{W}_{2}-\mathrm{W}_{1}\right) / \mathrm{A}
$$

$$
\begin{aligned}
& \mathrm{W}=\text { Dust content }(\mathrm{g}) \\
& \mathrm{W}_{2}=\text { Weight of sample leaf } \\
& \mathrm{W}_{1}=\text { Initial weight of leaf with dust } \\
& \mathrm{A}=\text { surface area of leaf }
\end{aligned}
$$

\subsection{Analysis and measurement of biochemical parameters}

Ascorbic acid content, total leave chlorophyll content, $p \mathrm{H}$ of leaf extract and relative water content of leaves of Ficus religiosa L. were measured by using following standard procedures.

\subsubsection{Measurement of ascorbic acid contents (AAC)}

Leaves ascorbic acid contents were estimated by following method [22].

Ascorbic Acid Content $(\mathrm{mg} / \mathrm{g})=[$ Eo $-($ Es-Et $) \times \mathrm{V}] /[\mathrm{W} \times \mathrm{V} 1] \times 1000$ where:

Eo $=$ Absorbance of blank

Es = OD (Optical Density) of pink Solution

Et $=$ OD (Optical Density) of bleached solution

$\mathrm{V} 1=$ Volume of the supernatant taken $\mathrm{V}=$ Total volume of mixture

$\mathrm{W}=$ Weight of fresh leaf taken

\subsubsection{Measurement of total chlorophyll content (TCh)}

Leaves chlorophyll content were measured by using standard method [23]. Took $2 \mathrm{mg}$ of fresh leaves, ground into the $20 \mathrm{~mL}$ of $80 \%$ acetone with the help of pestle and mortar and absorbance was read at $645 \mathrm{~nm}$ by using the spectrophotometer.

Total chlorophyll content was measured by using this formula.

Chlorophyll a $(\mathrm{mg} / \mathrm{g})$ fresh weight $=(\mathrm{A} 663 \times 0.0127+\mathrm{A} 645 \times 0.00269) \times 10 \times 50$

Chlorophyll b $(\mathrm{mg} / \mathrm{g})$ fresh weight $=(\mathrm{A} 645 \times 0.0229+\mathrm{A} 663 \times 0.00468) \times 10 \times 50$

Total Chlorophyll $(\mathrm{mg} / \mathrm{g})$ fresh weight $=(\mathrm{A} 663 \times 0.0202+\mathrm{A} 645 \times 0.00802) \times 10 \times 50$ 
where:

A663 = Absorbance at $663 \mathrm{~nm}$

A645 = Absorbance at $645 \mathrm{~nm}$

\subsection{3. $p \mathrm{H}$ of leaf extract}

Took $1 \mathrm{~g}$ of fresh leave of Ficus religiosa L., homogenized into $50 \mathrm{~mL}$ distilled water and $p \mathrm{H}$ of these plant extracts were estimated by a digital $\mathrm{pH}$ meter.

\subsubsection{Relative water content (RWC \%)}

Following method was used for the determination of RWC [24].

RWC $(\%)=[($ Fresh weight - Dry weight $) \div($ Saturated weight - Dry weight $) \times 100]$

\subsubsection{Air pollution tolerance index (APTI)}

APTI of the all plant sample was calculated by following formula [25].

$$
\mathrm{APTI}=[\mathrm{A}(\mathrm{T}+\mathrm{P})+\mathrm{R}] / 10
$$

where:

$$
\begin{aligned}
& \mathrm{A}=\text { Ascorbic acid content } \\
& \mathrm{P}=p \mathrm{H} \text { of leaf extract } \\
& \mathrm{R}=\text { Relative water content } \\
& \mathrm{T}=\text { Total chlorophyll content }
\end{aligned}
$$

\subsubsection{Statistical analysis}

Mean value of the samples were compared and significance of the data was determined through Analysis of Variance (ANOVA) by applying Duncan's Multiple Range Test (DMRT) at 0.05 (5\%) significance level [26].

\section{Results and discussions}

\subsection{Dust accumulation on leaves surface}

The maximum dust was accumulated on Ficus religiosa L. $\left(0.107 \pm 0.015 \mathrm{mg} / \mathrm{cm}^{2}\right)$ leaves that was collected from Mall road Lahore, minimum dust was noticed on leaves of control site (Changa Manga). The order of selected site according to dust accumulation (Table 1) was Mall road $(0.107 \pm 0.0015$ $\left.\mathrm{mg} / \mathrm{cm}^{2}\right)>$ Jail road $\left(0.076 \pm 0.0024 \mathrm{mg} / \mathrm{cm}^{2}\right)>$ Canal $\operatorname{road}\left(0.0317 \pm 0.0021 \mathrm{mg} / \mathrm{cm}^{2}\right)>$ control $\left(0.0025 \pm 0.00076 \mathrm{mg} / \mathrm{cm}^{2}\right)$. Dust accumulation was more on plants leaves growing at roadside due to vehicular activity and capturing dust with gentle wind. These dust particles contain several remnants of combustion of fuel and it is also reported that these micro elements get absorbed by the plants and cause problems for metabolic activities.

Table 1. Dust accumulation on leaves surface of Ficus religiosa L. from selected sites

\begin{tabular}{|c|c|c|}
\hline S. No & Road sides & Dust content $\left(\mathbf{m g} / \mathbf{c m}^{\mathbf{2}}\right)$ \\
\hline 1 & Control & $\mathbf{0 . 0 0 2 5} \mathbf{a} \pm \mathbf{0 . 0 0 0 7 6}$ \\
\hline 2 & Canal road & $0.0317 \mathrm{~b} \pm 0.0021$ \\
\hline 3 & Jail road & $0.076 \mathrm{c} \pm 0.0024$ \\
\hline 4 & Mall road & $0.107 \mathrm{~d} \pm 0.0015$ \\
\hline 5 & Mean & $\mathbf{0 . 0 7 1 6 b c} \pm \mathbf{0 . 0 0 0 6 3}$ \\
\hline
\end{tabular}

Mean values followed by different alphabets showed variations among values at $\mathrm{p}=0.05$

\subsection{Leaf area}

Leaves collected from the control site had more area compared to leaves collected from polluted site (Table 2). The order of selected sites according to leaf area was control $\left(1542 \pm 16.42 \mathrm{~mm}^{2}\right)>$ canal road $\left(1435 \pm 13.2 \mathrm{~mm}^{2}\right)>$ Jail $\operatorname{road}\left(1416 \pm 14.3 \mathrm{~mm}^{2}\right)>$ Mall $\operatorname{road}\left(1251 \pm 11.5 \mathrm{~mm}^{2}\right)$. 
Table 2. Leaf area $\left(\mathrm{mm}^{2}\right)$ of Ficus religiosa L. from selected sites

\begin{tabular}{|c|c|c|}
\hline S. No & Road sides & Leaf area $\left(\mathbf{m m}^{\mathbf{2}}\right)$ \\
\hline 1 & Control & $\mathbf{1 5 4 2 d} \pm \mathbf{1 6 . 4 2}$ \\
\hline 2 & Canal road & $1435 \mathrm{~d} \pm 13.2$ \\
\hline 3 & Jail road & $1416 \mathrm{c} \pm 14.3$ \\
\hline 4 & Mall road & $1251 \mathrm{a} \pm 11.5$ \\
\hline 5 & Mean & $\mathbf{1 3 6 7 c d} \pm \mathbf{1 4 . 2 5}$ \\
\hline
\end{tabular}

Mean values followed by different alphabets showed variations among values at $p=0.05$

\subsection{Ascorbic acid content (mg/g)}

Ascorbic Acid is a natural antioxidant which increase the plant resistance against the air pollution. The value of Ascorbic Acid content of Ficus religiosa L. (Table 3) growing at different road sides ranged from $0.4 \mathrm{mg} / \mathrm{g}$ to $0.75 \mathrm{mg} / \mathrm{g}$. The order of selected sites according to AAC was Mall road $(0.75 \pm 0.021$ $\mathrm{mg} / \mathrm{g})>$ Jail road $(0.68 \pm 0.05 \mathrm{mg} / \mathrm{g})>$ Canal road $(0.61 \pm 0.032 \mathrm{mg} / \mathrm{g})>$ control $(0.4 \pm 0.041 \mathrm{mg} / \mathrm{g})$. Maximum AAC content was recorded in the samples of Ficus religiosa L. collected from Mall road Lahore which reflects more resistance to air pollution compared to other samples. Ascorbic Acid is a stress reducing factor and is present in pollution tolerant species.

Table 3. Ascorbic acid content (mg/g) of Ficus religiosa L. from selected sites

\begin{tabular}{|c|c|c|}
\hline S. No & Road sides & Ascorbic Acid content $(\mathbf{m g} / \mathbf{g})$ \\
\hline 1 & Control & $\mathbf{0 . 4 0 a} \pm \mathbf{0 . 0 4 1}$ \\
\hline 2 & Canal road & $0.61 \mathrm{~b} \pm 0.032$ \\
\hline 3 & Jail road & $0.68 \mathrm{~b} \pm 0.05$ \\
\hline 4 & Mall road & $0.75 \mathrm{c} \pm 0.021$ \\
\hline 5 & Mean & $\mathbf{0 . 6 8 b} \pm \mathbf{0 . 0 2 1}$ \\
\hline
\end{tabular}

Mean values followed by different alphabets showed variations among values at $\mathrm{p}=0.05$

\subsection{Total chlorophyll content (mg/g)}

Chlorophyll content of plants is important to its photosynthetic activity, growth and development of biomass. Ficus religiosa L. growing along the polluted roadsides showed variation in their chlorophyll content. These variations may be attributed to genetic variation and other environmental conditions. The value of chlorophyll content of Ficus religiosa L. at different roadsides ranged from $7.96 \mathrm{mg} / \mathrm{g}$ to 14.34 $\mathrm{mg} / \mathrm{g}$. The order of selected sites according to chlorophyll content was Control $(14.34 \pm 0.011 \mathrm{mg} / \mathrm{g})>$ canal road $(9.1938 \pm 0.015 \mathrm{mg} / \mathrm{g})>$ Jail road $(8.36 \pm 0.023 \mathrm{mg} / \mathrm{g})>$ Mall road $(7.96 \pm 0.016 \mathrm{mg} / \mathrm{g})$. Maximum chlorophyll content was recorded in the samples of Ficus religiosa L. collected from Control site (Changa manga) compared to other samples from polluted roadside (Table 4).

Table 4. Total chlorophyll content (mg/g) of Ficus religiosa $\mathrm{L}$. from selected site

\begin{tabular}{|c|c|c|}
\hline S. No & Road sides & Total chlorophyll content $(\mathbf{m g} / \mathbf{g})$ \\
\hline 1 & Control & $\mathbf{1 4 . 3 4 c} \pm \mathbf{0 . 0 1 1}$ \\
\hline 2 & Canal road & $9.19 \mathrm{~b} \pm 0.015$ \\
\hline 3 & Jail road & $8.36 \mathrm{~b} \pm 0.023$ \\
\hline 4 & Mall road & $7.96 \mathrm{a} \pm 0.016$ \\
\hline 5 & Mean & $\mathbf{8 . 5 0 b} \pm \mathbf{0 . 0 1 7}$ \\
\hline
\end{tabular}

Mean values followed by different alphabets showed variations among values at $p=0.05$

\section{5. $p \mathrm{H}$ of leaf extract}

$p \mathrm{H}$ of leaf extract is a sensitive indicator of air pollution. Higher level of $p \mathrm{H}$ indicate that plants with higher $p \mathrm{H}$ shows tolerance under polluted condition. The value of leaf extract $p \mathrm{H}$ of Ficus religiosa $\mathrm{L}$. growing at different roadsides ranged from 6.39 to 8.10. The order of selected sites according to $p \mathrm{H}$ was Control $(8.10 \pm 0.014)>$ Canal road $(7.99 \pm 0.023)>$ Jail road $(7.12 \pm 0.014)>$ Mall road $(6.39 \pm 0.015)$. 
Maximum leaf extract $p \mathrm{H}$ was recorded in the samples of Ficus religiosa $\mathrm{L}$. collected from Control site (Changa manga) as compared to other samples from polluted roadside (Table 5). Leaf extract $p \mathrm{H}$ was reduced in the presence of acidic pollutants. $p \mathrm{H}$ exponential decrease with increase in vehicular pollution.

Table 5. $p \mathrm{H}$ of leaf extract of Ficus religiosa $\mathrm{L}$. from selected sites

\begin{tabular}{|c|c|c|}
\hline S. No & Road sides & $\boldsymbol{p H}$ \\
\hline 1 & Control & $\mathbf{8 . 1 0 b} \pm \mathbf{0 . 0 1 4}$ \\
\hline 2 & Canal road & $7.99 \mathrm{a} \pm 0.023$ \\
\hline 3 & Jail road & $7.12 \mathrm{a} \pm 0.014$ \\
\hline 4 & Mall road & $6.39 \mathrm{c} \pm 0.015$ \\
\hline 5 & Mean & $\mathbf{7 . 1 7 a c} \pm \mathbf{0 . 0 1 8}$ \\
\hline
\end{tabular}

Mean values followed by different alphabets showed variations among values at $\mathrm{p}=0.05$

\section{6. \% Relative water content (RWC\%)}

Relative water content within the plant body are helpful in maintaining the physiological balance under stressful condition such as air pollution. Relative water content of plants is responsible for normal function of plant biological processes. The value of Relative water content of Ficus religiosa L. growing at different roadsides ranged from $85 \%$ to $96.6 \%$. The order of selected sites according to RWC was Mall road $(96.6 \pm 0.069 \%)>$ Jail road $(92 \pm 0.065 \%)>$ Canal road $(89 \pm 0.086 \%)>$ Control $(85 \pm 0.082$ $\%)$ MaximumRWC was recorded in the samples of Ficus religiosa L. collected from Mall road as compared to other samples from other sites (Table 6).

Table 6. Relative water content of Ficus religiosa L. from selected sites

\begin{tabular}{|c|c|c|}
\hline S. No & Road sides & RWC \% \\
\hline 1 & Control & $\mathbf{8 5 a} \pm \mathbf{0 . 0 8 2}$ \\
\hline 2 & Canal road & $89 \mathrm{a} \pm 0.086$ \\
\hline 3 & Jail road & $92 \mathrm{~b} \pm 0.065$ \\
\hline 4 & Mall road & $96.6 \mathrm{c} \pm 0.069$ \\
\hline 5 & Mean & $\mathbf{9 2 . 5 b} \pm \mathbf{0 . 0 7 6}$ \\
\hline \multicolumn{2}{|c|}{ Mean values followed by different alphabets showed variations among values at $\mathrm{p}=0.05$}
\end{tabular}

\subsection{Air pollution tolerance index (APTI)}

Plants response to air pollution can be calculated by Air pollution Tolerance index. It is an index used to determine the resistance of plants toward air pollution. APTI value was estimated by using the four biochemical parameters namely Ascorbic Acid content, Total Chlorophyll content, $p \mathrm{H}$ of leaf extract and Relative water content in plants leaves. The value of APTI (Table 7) Ficus religiosa L. growing at different roadsides ranged from 10.73 to 9.39. The order of selected sites according to APTI was Mall road $(10.73 \pm 0.019)>$ Jail road $(10.31 \pm 0.015)>$ Canal road $(9.93 \pm 0.023)>$ Control $(9.39 \pm$ 0.012). Maximum APTI was recorded in the samples of Ficus religiosa L. collected from Mall road which means that these samples showed higher tolerance toward air pollution. Plants with high value of APTI works as pollution sink. These plants are planted in an area that are facing the air pollution problems.

Table 7. Air pollution Tolerance index (APTI) of Ficus religiosa L.

\begin{tabular}{|c|c|c|c|c|c|c|}
\hline $\begin{array}{c}\text { S.No. } \\
\#\end{array}$ & Road Sides & $\begin{array}{c}\text { Ascorbic Acid } \\
\text { content }(\mathbf{m g} / \mathbf{g})\end{array}$ & $\begin{array}{c}\text { Total chlorophyll } \\
\text { content }(\mathbf{m g} / \mathbf{g})\end{array}$ & $\mathbf{R W C}$ \% & $\boldsymbol{p H}$ & APTI \\
\hline 1 & Control & $\mathbf{0 . 4 a} \pm \mathbf{0 . 0 4 1}$ & $\mathbf{1 4 . 3 4 d} \pm \mathbf{0 . 0 1 1}$ & $\mathbf{8 5 a} \pm \mathbf{0 . 0 8 2}$ & $\mathbf{8 . 1 0 b} \pm \mathbf{0 . 0 1 4}$ & $\mathbf{9 . 3 9 c} \pm \mathbf{0 . 0 1 2}$ \\
\hline 2 & Canal road & $0.61 \mathrm{~b} \pm 0.032$ & $9.19 \mathrm{~b} \pm 0.015$ & $89 \pm \mathrm{a} 0.086$ & $7.99 \mathrm{a} \pm 0.023$ & $9.93 \mathrm{~d} \pm 0.023$ \\
\hline 3 & Jail road & $0.68 \mathrm{~b} \pm 0.05$ & $8.36 \mathrm{~b} \pm 0.023$ & $92 \mathrm{~b} \pm 0.065$ & $7.12 \mathrm{a} \pm 0.014$ & $10.31 \mathrm{~b} \pm 0.015$ \\
\hline 4 & Mall road & $0.75 \mathrm{c} \pm 0.021$ & $7.96 \mathrm{a} \pm 0.016$ & $96.6 \mathrm{c} \pm 0.069$ & $6.39 \mathrm{c} \pm 0.015$ & $10.73 \mathrm{a} \pm 0.019$ \\
\hline 5 & Mean & $\mathbf{0 . 6 8 b} \pm \mathbf{0 . 0 2 1}$ & $\mathbf{8 . 5 0 b} \pm \mathbf{0 . 0 1 7}$ & $\mathbf{9 2 . 5 b} \pm \mathbf{0 . 0 7 6}$ & $\mathbf{7 . 1 7 a c} \pm \mathbf{0 . 0 1 8}$ & $\mathbf{1 0 . 3 2 b} \pm \mathbf{0 . 0 2 3}$ \\
\hline
\end{tabular}

Mean values followed by different alphabets showed variations among values at $p=0.05$ 
Air pollution has great impact not only on human health, but also on plants, especially those plants that are directly exposed to air pollution. The stress caused by air pollution can alter the leaf size and physicochemical characteristics of plants such as chlorophyll content, ascorbic acid content, relative water content, $p \mathrm{H}$ and several proteins that regulate under air pollution stress. Ficus religiosa $\mathrm{L}$. is the native tree of Lahore city and is extensively planted along the roadsides due to its large cover or high biomass. The experiment was conducted to measure the dust accumulations on the leaves surface area and Air pollution Tolerance Index of the Ficus religiosa L. existing on the three main busy roads of the Lahore. Data were compared with the control plants, which were grown in Changa manga District Kasur. This study revealed that the higher quantities of the dust accumulations were recorded on the plant leaves surface that were collected from the Mall road Lahore. Minimum dust accumulations were recorded on the control plant leaves surface. In the present study leaves areas of the Ficus religiosa L. were also noted. It was observed that the leaf samples of the road side plants was less in their size (leaf area) as compared to the leaf samples of the control sites.

Many plants having the antioxidants in which the ascorbic acid is the most important. It increase the tolerance of plants against the many environment stresses such as air pollution [27, 28]. Current study revealed that the ascorbic acid contents are high in the plants planted on the roadsides of major roads of the Lahore. It means the plants of the urban areas (having the higher concentration air pollution) are in the stress condition as compared to the plants grown on the control or rural environment. Current study shown that AA and pollution level are interconnected with each other, and the plants of the polluted area have the higher level of ascorbic acid [29, 30]. The reason is the formation of ROS (Reactive Oxygen Species) during the photo-oxidation process.

Between the bio-chemical parameters, the chlorophyll concentration is the most important indicator of the plants on which we evaluate the effects of air pollution because it has the major role in the plant development, metabolism and growth [31]. The present study shows that the control plants have higher level of total chlorophyll contents compared to the samples collected along the roadsides of three main busy road of the city Lahore. The study conducted by Jyothi and Jaya in 2010 have reported similar results showing that plants grown closer to road (10 $\mathrm{m}$ away from road) have lower total chlorophyll contents compared to the plants grown away $(200 \mathrm{~m})$ from the road. These changes are attributed to higher pollution levels in the area related with the roads traffic [32].

Another study have reported the connection of vehicular density with total chlorophyll content (TCh), leaf senescence, photosynthetic activity and stomatal conductance [33]. The decrease in the TCh contents of the leaves is due to the air pollution, and the chloroplast is the major site of the attack of major air pollutant such like $\mathrm{NO}_{2}$ and $\mathrm{SO}_{2}$ [29,34-36]. Air pollutants enter in the leaf tissue by the stomata and in this way they degrade the chloroplast of plants and lower the total chlorophyll of the plants leaves [31].

In the current study samples of the control plants have shown increased $p \mathrm{H}$ compared to the plants which are grown along the different roadside. These results can be attributed to air pollutants, which is also supported by a past study which reported that reduction in $p \mathrm{H}$ values is due to the presence of $\mathrm{NO}_{2}$, $\mathrm{SO}_{2}$, or other acidic pollutants released in the vehicular and industrial emission [28]. Minor acidic $p \mathrm{H}$ of the leaf depicts the good interaction between air pollution induced stress and increased sensitivity of the plants that results in lowering the process of photosynthesis in the plants [29, 31, 37].

Current study also revealed that the plants grown along the roadsides have the higher levels of relative water contents (RWC) compared to the control plants. This difference shows the plant response to overcome air pollution induced physiological deviations. RWC within the plant body are helpful in maintaining the physiological balance under stressful condition such as air pollution. RWC of plants is responsible for normal function of plant biological processes [30]. RWC are also associated with the permeability of the protoplasts in the cells and can cause loss of dissolved nutrients and water, resulting in the early senescence of leaves [34]. Maintenance of RWC by the plants may control the stress tolerance of different plants species. The plants with higher RWC have greater stress tolerance capacity. 
Plants response to air pollution can be estimated by Air pollution tolerance index. It is a parameter which can be used to determine the resistance of different plants species toward air pollution. It can be calculated by using the four biochemical parameters including ascorbic acid content, total chlorophyll content, $p \mathrm{H}$ of leaf extract and RWC in plants leaves. The value of air pollution tolerance index of Ficus religiosa L. growing at different roadsides ranged from 9.39 to 10.73. Maximum air pollution tolerance index was recorded in the samples collected from Mall road which showed higher pollution levels along the road and higher plant tolerance toward air pollution. Plants having higher air pollution tolerance index are more tolerant to the air pollution while the plants with lower air pollution tolerance index have a low tolerance [28].

\section{Conclusions}

It can be concluded from the results that Ficus religiosa L. planted along the Mall road, Jail road and canal road showed tremendous potential against ever increasing pressure of air pollution in one of the biggest city of Pakistan. Highest value APTI in plant samples of Mall road was recorded followed by plant samples of Jail road and Canal road. This could be due to the variation in density of plantation of trees in all these three roads as Mall road is considered as one of the heavily planted road of Lahore with large number of diversity of tree species, which can be helpful in mitigate the effect of air pollution collectively as compared to the other roads. On other side less amount of plantation can be found on these two roads which could be major factor in having less tolerance potential of the $F$. religiosa against air pollution. Moreover, physiochemical characters of $F$. religiosa planted on the polluted roads of Lahore, Pakistan showed alterations compared to control site. The APTI values of $F$. religiosa is higher in polluted sites compared to cleaner area. It depicts that they are considerably affected by the prevailing air pollution in Lahore city.

\section{References}

1.NOWAK, D.J., CRANE, D.E., Carbon storage and sequestration by urban trees in the USA, Env. Poll., 116, 2002, 381-389.

2.ORUN, A., LIZONDO, D., GOODYER, E., PALUSZCZYSZYN, D., Use of Bayesian inference method to model vehicular air pollution in local urban areas, Trans. and Env., 63, 2018, 236-243.

3.SHIRWANI, R., GULZAR, S., ASIM, M., UMAIR, M., AL-RASHID, M.A., Control of vehicular emission using innovative energy solutions comprising of hydrogen for transportation sector in Pakistan: A case study of Lahore City, Int. J. of Hyd. En., 45, 2019, 16287-16297.

4.SIDDIQUI, S., SHIRAZI, S.A., ALI, A., A Floristic Analysis of selected parks in Lahore Pakistan, JPUHS., 29, 2016, 182-195.

5ASHRAF, A., BUTT, A., KHALID, I., ALAM, R. U., AHMAD, S. R., Smog analysis and its effect on reported ocular surface diseases: A case study of 2016 smog event of Lahore, Atmospheric Environment, 198, 2019, 257-264.

6.MIRZA, A., KAZMI, S., SHIRAZI, S., Identification and Analysis of a sustainable system of road traffic pattern in Lahore city, Pakistan Journal of Science, 10, 2013, 420-425.

7.KHALID, N., MASOOD, A., NOMAN, A., AQEEL, M., QASIM. M., Study of the responses of two biomonitor plant species (Datura alba \& Ricinus communis) to roadside air pollution, Chemosphere, 235, 2019, 832-841.

8.REŞITOGLU, İ. A., NOx Pollutants from diesel vehicles and trends in the control technologies, Environmental Science, 2018, 10.5772/intechopen.81112.

9.NANDY, A., TALAPATRA, S. N., BHATTACHARJEE, P., CHAUDHURI, P., MUKHOPADHYAY, A., Assessment of morphological damages of leaves of selected plant species due to vehicular air pollution, Kolkata, India, International Letters of Natural Sciences, 9, 2014, 76-91.

10.KHARE, M., NAGENDRA. S. S., Artificial neural networks in vehicular pollution modelling, Springer, 978-3-540-37418-3 2007,1-242 
11.PANDEY, A. K., PANDEY, M., MISHRA, A., TIWARY, S. M., Tripathi, B., Air pollution tolerance index and anticipated performance index of some plant species for development of urban forest, Urban Forestry \& Urban Greening, 14, 2015, 866-871.

12.KOVALCHUK, I., KOVALCHUK, O., Transgenic plants as sensors of environmental pollution genotoxicity, Sensors, 8, 2008, 1539-1558.

13.CHAUDHRY, N. A., Lahore: Glimpses of a Glorious Heritage, Sang-E-Meel Publication, 9693509447. 1998,1-556.

14.CHANDRASEKAR, S., BHANUMATHY, M., PAWAR, A., SOMASUNDARAM, T., Phytopharmacology of Ficus religiosa, Pharmacognosy Reviews, 4, 2010, 195-199.

15.SIVALINGAM, D., RAJENDRAN, R., ANBARASAN, K., Studies on DNA barcoding of sacred plant-Ficus religiosa L., Journal of Applied and Advanced Research, 1, 2016, 29- 39.

16.NOWAK, D. J., HOEHN, R., CRANE, D. E. Oxygen production by urban trees in the United States, Arboriculture \& Urban Forestry, 33, 2007, 220-226.

17.HESAMI, M., DANESHVAR, M. H., YOOSEFZADEH-NAJAFABADI, M., ALIZADEH, M., Effect of plant growth regulators on indirect shoot organogenesis of Ficus religiosa through seedling derived petiole segments, Journal of Genetic Engineering and Biotechnology, 16, 2018, 175-180.

18.KUMARI, M., SHARMA, A., JAGANNADHAM, M., Religiosin B, a milk-clotting serine protease from Ficus religiosa, Food Chemistry, 13, 2012, 1295-1303.

19.NAYAK, A., MADAN, S., MATTA, G., Evaluation of Air Pollution Tolerance Index (APTI) and Anticipated Performance Index (API) of Some Plants Species in Haridwar City, International Journal for Environmental Rehabilitation and Conservation, IX, 2018,1-7.

20.RINI, S., MASUD, Z.A., NASRULLAH, N., BEY, A., TJITROSEMITO, S., Tolerance levels of roadside trees to air pollutants based on relative growth rate and air pollution tolerance index, HAYATI Journal of Biosciences, 15, 2008, 1-123.

21.RAI, P. K., PANDA. L. L., Leaf dust deposition and its impact on biochemical aspect of some roadside plants of Aizawl, Mizoram, North East India, International Research Journal of Environment Sciences, 3(11) 2014,14-19.

22.KELLER, T., SCHWAGER. H., Air pollution and ascorbic acid, European Journal of Forest Pathology, 7, 1977, 338-350.

23.SINGH, S., RAO, D., AGRAWAL, M., PANDEY, J., NARYAN, D., Air pollution tolerance index of plants, Journal of Environmental Management, 32, 1991, 45-55.

24.SIVAKUMARAN, HALL, S. M., Effects of age and water stress on endogenous levels of plant growth regulators in Euphorbia lathyrus L., Journal of Experimental Botany, 29, 1978, 195-205.

25.SINGH, S.K., RAOM, D.N., AGRAWAL, J., PANDEY, D., NARYAN, A., Air pollution tolerance index of plants, Journal of Environmental Management, 32, 1991, 45-55

26.STEEL R.G.D., TORRIE, J.H., Principles and Procedures of Statistics-A Biometric Approach. $3^{\text {rd }}$ edition. McGraw-Hill Publishing Company: Toronto. pp. 672, 1996.

27.JOSHI, P., SWAMI, A., Physiological responses of some tree species under roadside automobile pollution stress around city of Haridwar, India, The Environmentalist, 27, 2007, 365-374.

28.RAI, P. K., PANDA, L. L., CHUTIA, B. M., SINGH, M. M., Comparative assessment of air pollution tolerance index (APTI) in the industrial (Rourkela) and non-industrial area (Aizawl) of India: An ecomanagement approach, African Journal of Environmental Science and Technology, 7, 2013, 944-948.

29.SEYYEDNJAD, S., MAJDIAN, K., KOOCHAK, H., NIKNEJAD, M., Air pollution tolerance indices of some plants around industrial zone in south of Iran, Asian J. Biol. Sci., 4, 2011, 300-305.

30.MEERABAI, G., RAMANA, V.C., RASHEED, M., Effect of industrial pollutants on physiology of Cajanus cajan (L.) Fabaceae, International Journal of Environmental Sciences, 2, 2012, 1901-1906.

31.TRIPATHI, A., GAUTAM, M, Biochemical parameters of plants as indicators of air pollution, Journal of Environmental Biology, 28, 2007, 127-32.

32.JYOTHI, S. J., JAYA, D., Evaluation of air pollution tolerance index of selected plant species along roadsides in Thiruvananthapuram, Kerala, Journal of Environmental Biology, 31, 2010, 379-386. 
33.HONOUR, S. L., BELL, J. N., ASHENDEN, T. W., CAPE, J. N., Power, S. A., Responses of herbaceous plants to urban air pollution: effects on growth, phenology and leaf surface characteristics. Environmental Pollution, 157, 2009, 1279-1286.

34.RADHAPRIYA, P., GOPALAKRISHNAN, A. N., MALINI, P., RAMACHANDRAN, A., Assessment of air pollution tolerance levels of selected plants around cement industry, Coimbatore, India, Journal of Environmental Biology, 33, 2012:635-41.

35.SEYYEDNEJAD, S. M., KOOCHAK, H., Some morphological and biochemical responses due to industrial air pollution in Prosopis juliflora (Swartz) DC plant, African Journal of Agricultural Research, 8, 2013,1968-1974.

36.YADAV, S., SINGH, M., KUMAR, V., Effect of air pollutions in Biochemical parameters of selected plant species of Jhansi City (Uttar Pradesh), International Journal of Emerging Technologies in Computational and Applied Sciences, 6, 2013, 168-173.

37.THAKAR, B., MISHRA, P., Dust collection potential and air pollution tolerance index of tree vegetation around Vedanta Aluminum Limited, Jharsuguda. The Bioscan, 3, 2010, 603-612.

Manuscript received: 15.01 .2021 